\title{
Project studies
}

What it is, where it is going

\section{Geraldi, Joana; Söderlund, Jonas}

\section{Published in:}

International Journal of Project Management

Link to article, DOI:

10.1016/j.jproman.2017.06.004

Publication date:

2018

\section{Document Version}

Peer reviewed version

Link back to DTU Orbit

Citation (APA):

Geraldi, J., \& Söderlund, J. (2018). Project studies: What it is, where it is going. International Journal of Project Management, 36(1), 55-70. https://doi.org/10.1016/j.ijproman.2017.06.004

\section{General rights}

Copyright and moral rights for the publications made accessible in the public portal are retained by the authors and/or other copyright owners and it is a condition of accessing publications that users recognise and abide by the legal requirements associated with these rights.

- Users may download and print one copy of any publication from the public portal for the purpose of private study or research.

- You may not further distribute the material or use it for any profit-making activity or commercial gain

- You may freely distribute the URL identifying the publication in the public portal

If you believe that this document breaches copyright please contact us providing details, and we will remove access to the work immediately and investigate your claim. 


\title{
Project Studies: What It Is, Where It Is Going
}

\author{
Joana Geraldi, Technical University of Denmark \\ Jonas Söderlund, BI Norwegian Business School
}

Article In Press, available online:

Geraldi, Joana, and Jonas Söderlund. "Project studies: What it is, where it is going." International Journal of Project Management (2017). https://doi.org/10.1016/j.ijproman.2017.06.004

\begin{abstract}
Project organising is a growing field of scholarly inquiry and management practice. In recent years, two important developments have influenced this field: (1) the study and practice of projects have extended their level of analysis from mainly focussing on individual projects to focussing on micro- as well as macro-level concerns around projects; and (2) there has been a greater interest in different kinds of scholarly inquiry. Taken together, these two developments call for closer scrutiny of how the levels of analysis and the types of inquiry are related and benefit each other, and the explanations of project practices they could offer. To discuss avenues for future research on projects and project practice, this paper suggests the notion of project studies to better grasp the status of our field. We combine these two sets of ideas to analyse the status and future options for advancing project research: (1) levels of analysis; and (2) type of research. Analysing recent developments within project studies, we observe the emergence of what we refer to as type 3 research, which reconciles the need for theoretical development, practice engagement and pragmatic avenues to move away from accepted yet unhelpful assumptions about projects and project organising. The paper ends with suggestions for an agenda for future research, which offer project scholars a variety of options to position themselves in the field of project studies, and to explore opportunities in the crossroads between levels of analysis and types of research.
\end{abstract}

Keywords: levels of analysis, research, project studies, project organising, scholarship, sociology of science, project management. 


\section{Executive Summary}

Scholarly inquiry and management practice in projects is diversifying rapidly, which may segregate the field, but could also constitute an opportunity. For example, the diversity of 'organisations' or forms of 'organising' filled the field with new ideas and intellectual challenges. To take advantage of such developments, organisational scholars had to consider different forms of organising as part of 'organisation studies', and continuously adapt their frames of reference and forms of conceptualising organisations as a 'research field' and a 'research object'. Concomitantly, they embraced alternative research interests, ontologies and epistemologies, which today enrich the field. Such dynamics build on scholarly reflexivity and could also, we believe, be fostered in project research.

Thus, responding to the diversification of the field, and inspired by the notion of 'organisation studies', we present the case of 'project studies', which acts as an umbrella for the studies in, on and around projects. 'Project studies' is novel as it does not propose an alternative perspective on projects, but instead calls for an inclusive and integrative research field for all perspectives, fostering vibrant dialogue and debate that welcomes different opinions and perspectives.

The aim of the present paper is to demonstrate the value of the notion of project studies and to call for a reflexive scholarly practice capable of navigating diversity by positioning their research in contrast with others. In particular, we focus on two recent developments that have contributed to the diversification of the field and offered new options for project scholars:

(1) the study and practice of projects have extended their level of analysis from mainly focussing on individual projects to focussing on micro- as well as macro-level concerns around projects; and

(2) there has been a greater interest in different kinds of scholarly inquiry, which we looked through the lenses of the three deep-seeded human interests proposed by Habermas: a) The traditional positivist tradition aims to 'solve the problems' of project organising and increase its efficiency and effectiveness through better understanding of causal relationships surrounding projects. b) Interpretative research is 
grounded on our inherent interest to understand the world around us, but not necessarily 'solve' it. Rather, this research explores perceptions, behaviours and sees the world not so much in terms of causal-links, but complex networks with interesting cases and possibilities for learning. c) Emancipatory research is driven by emancipatory interest and the pragmatic desire for changes in the status quo, not in an optimisation lens as in typical normative and positivist research. Rather, it is the reorganisation of inherent contradictions, giving voice to minorities while addressing major economic and social problems. We termed them type 1, type 2 and type 3 , respectively.

The juxtaposition of levels of analysis and types of research offers a matrix with nine areas to position research contributions and to identify potential opportunities in the field of project studies. We argue the framework can be used to identify new opportunities for research as some 'cells' in the grid are less populated than others for different topics of study. Usually, extending current treatments of problems and topics to different levels of analysis and types of research form potentially insightful research in project studies. We would also welcome the strengthening of type 3 research across the three primary levels of analysis addressed in the present paper.

This paper provides a framework to encourage project scholars to reflect and become even more aware of nature and conduct of their research: the kinds of knowledge and interests they pursue, as well as the focus of their research. Our framework and analysis are exploratory and only build a tentative foundation for further exploration. We hope more will come that continue along these lines as well as criticise the main ideas presented here. 


\section{Introduction}

Research on projects is diversifying at a rapid pace. We observe scholars using alternative theories, epistemologies and ontologies (Padalkar and Gopinath, 2016; Smyth and Morris, 2007), as well as moving the focus from the single project to embracing micro- (individual, team) and macro-level (organisations, society) concerns (Pollack and Adler, 2014; Söderlund, 2011). Such empirical, theoretical and methodological diffusion is welcomed given the impact, magnitude, frequency and diversity of contemporary projects, and the many challenges surrounding the numerous projects in our society (e.g., Flyvbjerg et al., 2009; Resolution, 2009; Winch, 2013). However, such diversity may segregate project management/project organising as an academic field for good or bad, as it can hamper the development of a common language, which can potentially threaten the accumulation of knowledge and a genuine and constructive dialogue within the field as well as between project scholars, scholars in other fields and practitioners. Accordingly and paradoxically, the popularity of projects in practice and academia could weaken the field as we know it. ${ }^{1}$ Yet, simultaneously, such diffusion could also constitute an opportunity. For example, the diversity of 'organisations' or forms of 'organising' across countless contexts did not weaken 'organisation studies'. On the contrary, the variety filled the field with new ideas and intellectual challenges. To take advantage of such developments, organisational scholars had to consider different forms of organising as part of 'organisation studies', and continuously adapt their frames of reference and forms of conceptualising organisations as a 'research field' and a 'research object'. Concomitantly, they embraced alternative research interests, ontologies and epistemologies, which today enrich the field. Such dynamics build on scholarly reflexivity and could also, we believe, be fostered in the field of project research.

Thus, responding to the diversification of the field, and inspired by the notion of 'organisation studies', we present the case of 'project studies' - a novel and alternative way of understanding the field at its present

\footnotetext{
${ }^{1}$ We would like to thank Dr Mattias Jacobsson and Dr Sofia Pemsel for discussions that helped shape the arguments presented in this paragraph.
} 
stage of development, which acts as an umbrella for the studies in, on and around projects. The aim of the present paper is to demonstrate the value of the notion of project studies and to suggest a framework to conceptualise core research choices in this area. Our first question revolves around what constitutes 'project studies'. Our second question is concerned with the future of project studies. To address the second question, we consider research as a social process, and thus position project scholars and their research choices at the centre of project studies. Three central research choices are: what to study in project contexts, i.e. which level of analysis to explore and what object of analysis; why to study, i.e. what kind of knowledge is produced and how will it contribute to the field; and finally, deriving from the first two, how to study (ontological, epistemological and methodological) aspects and issues pertaining to projects. Research on projects and project organising is diversifying precisely around these three core areas. Our framework attempts to capture this diversity. We build and expand on Habermas' knowledge constitutive theory (Habermas, 1972), and propose a framework that connects different types of knowledge interests proposed by Habermas with different levels of analysis. The framework is intended to foster reflexivity, and thereby revitalise existing research programs and point to new options and avenues for future studies.

In the next sections, we elaborate on the concept of 'project studies'. We then discuss the relevance of the project scholar in shaping the nature and dynamics of project studies, and subsequently call for reflexivity to yield opportunities following the emerging diversification of this field. We then propose a framework to support the development of such reflexivity. The framework builds on the diversification of knowledge interests and levels of analysis among scholarly inquiries, and offers an agenda for future research for project studies.

\section{Conceptualising project studies}

We contend that the labels currently used for project management and project organising as an academic field no longer accommodate all the issues and challenges that it entails. The changing nature of the field is captured in the developments in its leading journal - the International Journal of Project Management 
$(I J P M)$. The number of citations in the IJPM has increased steadily over the last five years, reaching a social normalised impact per paper (SNIP) factor of 2.56, which is higher than other project management journals and comparable to top-ranked operations management journals. Somewhat interestingly, this is the category where the IJPM is placed in the Association of Business Schools (ABS) journal ranking list. Although the IJPM is not comparable to specialised journals in other knowledge areas, such as innovation, marketing and strategy, the number of scholars reading the IJPM continually increases, and the interest from a widening range of scholarly fields is also noteworthy. This is important, as the high impact factor offers an attractive publication outlet and potential for academics who are pursuing careers within project studies, thereby increasing the quality of scholars and scholarly outcomes.

The nature of the research published in the journal has also changed. Historically, the IJPM has had a firm grounding in engineering management, construction management and project planning (Crawford et al., 2006; Kloppenborg and Opfer, 2002). Over the years, the journal has become more rooted in social science and management/organisation studies in a broader sense, and addresses a host of problems that are beyond what we historically have associated with project management. For example, Crawford et al. (2006) explored the topics covered in the IJPM and the Project Management Journal (PMJ) from 1994 to 2003, and identified a trend towards more strategic issues, such as marketing, scope management, strategic alignment and project evaluation, while topics such as quality management received less attention. This result is in line with Pollack and Adler's (2014) comprehensive study covering nearly 94,472 articles related to 'project management', including IJPM publications from 1962 to 2012, which identified a trend of moving from more technical and engineering topics to embracing a broader organisational perspective. Similarly, Padalkar and Gopinath's (2016) review of over 250 articles in three key project management journals suggests a move from deterministic to explanatory and nondeterministic types of research. Thus, project scholars currently conduct different types of research with different focus areas. 
Moreover, project and general management research are increasingly being linked. Theoretical contributions and publication outlets have moved beyond the traditional project management journals. In parallel, scholars originally from other disciplines have gained increasing interest in the study of projects, and have brought with them alternative theoretical frameworks, disciplinary backgrounds and modes of conducting research (see for instance Davies and Hobday, 2005; Grabher and Ibert, 2014).

The diversity in scholarly backgrounds, empirical settings and theoretical angles concurs with the variety of terms and concepts used to describe projects and their impact on organisations and society. The list of terms and concepts is long, including project organising, project-led organisations, project-based organising, project networks, program management, project portfolio management, project society, project landscapes, projectification, programmification, project lineage, project ecologies and project networks, among others. Each term reveals a new empirical phenomenon or offers a novel perspective on wellknown phenomena. For example, while 'project management' - the classic term - most often refers to the processes, tools, techniques and concepts to manage the execution of a project, the 'management of projects' proposed by Morris (1994) extends the concept to the front-end, i.e. the strategic formation of the project.

The various names also represent distinct perspectives on projects (Jacobsson et al., 2015), schools of thought (Bredillet, 2010; Söderlund, 2011), methodologies (Crawford et al., 2006; Smyth and Morris, 2007) and paradigms (Pollack, 2007; van der Hoorn and Whitty, 2015; Williams, 2005). Most of these alternative terms represent a form of departure from classic project management as a 'method or 'tool'. We align with these attempts to downplay the narrow focus on project management as a separate activity, and avoid the risk of associating our research with a particular technique or management approach.

Names certainly matter (Geraldi and Teerikangas, 2009; Pellegrinelli, 2011), but what connects them matters as well. Jacobsson et al. (2015) applied Wittgenstein's family resemblance to projects and argue that the research and notion of projects are different yet connected as a 'family' of concepts. We draw on this idea and suggest 'project studies' as an integrating label for the family of studies in, on and around 
projects, which covers not only the notions described above, but also its distinct research objects, theoretical frames, ontologies and epistemologies. 'Project studies' is novel as it does not propose a perspective on projects, but instead calls for an inclusive and integrative research field for all perspectives, fostering vibrant dialogue and debate that welcomes different opinions and perspectives.

\section{Reflexive project scholarship and project studies}

Accompanying the integrating label 'project studies', the remainder of this paper offers an integrating framework to describe project studies at its current stage and to propose potential avenues for the future. Our point of departure for the development of our framework is the intrinsic relationship between project scholars and project studies. By project scholars, we mean the community of scholars studying projects (temporary organisations, project organising, the management of projects, project management, etc.). This includes the community of peers who usually organise and participate in the International Research Network on Organizing by Projects (IRNOP), the Engineering Project Organization Conference (EPOC), and/or the project tracks in the general organisation and management conferences, such as the European Academy of Management (EURAM) and the European Group for Organizational Studies (EGOS). Project scholars read, write and are involved in the editing of journals dedicated (although not exclusively) to projects, most notably, the IJPM, the PMJ and the International Journal of Managing Projects in Business.

The research community and the scholars within it matter. As is well-known research is a social process and a social practice (Chalmers, 1976; e.g. Kuhn, 1962; Merton, 1973); the research and the findings it produces are influenced by who the researchers are, their ideologies and convictions, the network, the research community and the wider contemporary 'Zeitgeist' (Merton, 1973). In this respect, as 'project scholars' frame, conduct and publish research, they produce, reproduce and change 'project studies'. Hence, project scholars shape the present and future of project studies.

We adopt an interpretative perspective to explore the relationship between project studies and project scholars. According to the interpretative perspective, the individual and world are inextricably linked 
through the person's lived experience of the world (Berger and Luckmann, 1966; Husserl, 1970; Schütz, 1945). Sandberg (2000) took an interpretative perspective to study the relationship between work and worker, and identified workers with different levels of conception of their work. Sandberg's idea has since been applied to explore the relationship between projects and program workers and their projects, and have yielded similar results (Borg and Söderlund, 2015; e.g. Partington et al., 2005). We can, therefore, infer that the relationship between scholar and research is developed through the lived experience of research, and the meaning that research takes on for the scholar in his or her experience of it (Sandberg, 2000). Hence, our research approach is intrinsically associated with our experiences, our communities and ourselves. This combination of factors makes us conceptualise research in different ways, i.e. focus on different objects of analysis, ask different questions, see and engage with the 'empirical world' differently, and aim to develop different kinds of knowledge.

Following this line of argument, diverse communities, like project studies, are faced with conflicting ideas and explanations, which can trigger reflexivity; that is, the ability to recognise that 'all forms of inquiry are paradigmatically circumscribed, and therefore truth claims, assumptions about reality and the ways in which we generate accurate theories should be challenged to reveal the inherent instability of knowledge' (Cunliffe, 2003, p. 984). Such debate and questioning are welcomed as they strengthen the field and its intellectual development.

Analytical frameworks offer an approach to foster such reflexivity, as they highlight the boundaries, assumptions, major findings, challenges and potential future of a field (Shapira, 2011). They also guide a search for gaps within and between areas of the framework. These frameworks are particularly useful in highly heterogeneous research fields, such as project studies, as they display the different research 'silos', thereby fostering cross-fertilisation (Knudsen, 2003). Söderlund adds that 'the combination of multiple perspectives and informed practice would then ... hopefully infuse a more insightful and penetrating research agenda' (Söderlund, 2011, p. 155). As a consequence, these frameworks can illustrate the current theoretical pluralism in the field, and assist and promote the study and integration of individual findings. It 
is thereby a means to identify both conflicts between research streams and potential overlaps and opportunities to build and extend current research, all of which can stimulate future research and scholarly debates. Moreover, frameworks can also help us reflect upon the questions we have already posed and rethink their relevance to the practice as well as the study of projects. Thus, frameworks are useful to exploit the diversity of the field, while assisting in moving it from a 'fragmented adhocracy' to a 'polycentric oligarchy' (Knudsen, 2003).

We therefore propose a framework that can potentially assist project scholars to make core choices and shape project studies. The framework captures two changes observed in project studies in the last decade:

a) The broadening of types of research. In this respect, we explore the kind of knowledge project scholars aim to develop and its respective types of interest and implicit values. Here, we use Habermas' knowledge-constitutive interest theory to develop three types of project studies.

b) The broadening of levels of analysis, reflecting the wider empirical world across diverse levels of analysis, and moving beyond projects and expanding from individual to societal levels. When looking at different levels of analysis, project scholars will develop alternative frames for projects, project practices and project studies, and thus conceptualise practice and academia differently. We use here the classic micro, meso and macro levels of analysis to guide our conceptual development.

The juxtaposition of these two dimensions form our framework. The framework is appropriate for three reasons. First, the two dimensions cover fundamental research design choices, namely, what is studied (level of analysis), why it is studied (knowledge-constitutive interest). Second, they capture key changes in our research field in the last decade and are, therefore, appropriate for discussing the current stage of the field. Finally, the framework guides reflexivity without looking inward to the already established themes. Instead, it looks for connections with other areas in management and beyond, such as sociology, innovation, strategy, etc. For example, how can psychology inform the individual level of analysis? How can sociology, philosophy and political sciences inform analysis at the societal level of analysis? And so 
on. In this regard, the framework encourages integration, not only within project studies but also between project studies and other research communities.

In the next sections, we explore these two dimensions separately and then in combination, and propose an initial research agenda.

\section{Types of project studies ${ }^{2}$}

\section{Habermas' theory of knowledge-constitutive interests}

This article builds on Habermas' theory of knowledge-constitutive interests to open the discussion on types of knowing in project studies. According to Habermas, human interests guide structures of work and authority, and influence how people think, inquire and create knowledge of the world. Hence, no type of knowledge is ever neutral but rather reflects our interests. Habermas (1972) identifies three distinct human interests rooted in the human existence as a social and biological species, and explains how these three knowledge interests are expressed in different types of research. Therefore, human interest is at the heart of research, as the human interest of the researcher will determine to a great extent the kind of knowledge that the research is likely to develop, as well as the most pertinent research methods. By establishing these different human interests, he purports to establish a critical social theory as a respectable and distinct form of knowledge to the then-dominant positivist philosophy of science and historicist hermeneutics.

The technical interest refers to the anthropologically deep-seated interest to control and predict the natural environment, which motivates classic positivistic research inquiry to uncover law-lie regularities. It conceptualises science as instrumental and objective, in search of 'truth', which is understood as verified facts through methodical experimentation, controlled observation, large sampling statistics, etc.

The interpretive or cultural-hermeneutic sciences are driven by the deep-seated practical interest to maintain or increase one's self and a mutual understanding in life. It is embedded in the pragmatic human need to communicate with others and to develop an inter-subjective understanding of their context and

\footnotetext{
${ }^{2}$ The three types of research were originally introduced in Geraldi and Söderlund (2016).
} 
relationships. Truth here is conceptualised as consensus or coherence - something is considered true if multiple people consider it to be true.

Finally, the emancipatory interest is 'aimed at the realization of autonomy from defective actions and utterances arising from social relations of power, domination and alienation', and hence, with a core interest in the desire to overcome dogmatism, compulsion and domination. Therefore, Habermas suggests a third human interest of self-reflection and reasoning. His ideas resonate with Kant and some of the core ideas of the Enlightenment. Habermas' search for the epistemic and normative basis for such critique culminated in his work, The Theory of Communicative Action (Habermas, 1985, 1981), which he developed later in his career. This theory explores language and communication as essential for rationality and reason, and argues that communicative action is the foundation for change; that is, a communication 'oriented to achieving, sustaining and reviewing consensus - and indeed a consensus that rests on the intersubjective recognition of criticisable validity claims' (Habermas, 1984, p. 17). Thus, Habermas' emancipation is not about critical reflection for its own sake. His emphasis is on the potential for transformation through human reasoning rooted in language and discourse analysis. Error! Reference source not found. summarises Habermas' three distinct 'ways of knowing'.

Table 1: Overview of Habermas' Theory of Knowledge-Constitutive Interests (based on Cicmil, 2006; Habermas, 1972; Tinning, 1992)

\begin{tabular}{|l|l|l|l|}
\hline $\begin{array}{l}\text { Framing } \\
\text { Attributes }\end{array}$ & Type 1 & Type 2 & Type 3 \\
\hline $\begin{array}{l}\text { Knowledge- } \\
\text { constitutive } \\
\text { interests }\end{array}$ & $\begin{array}{l}\text { Technical with a focus on } \\
\text { prediction and control }\end{array}$ & $\begin{array}{l}\text { Practical with a focus } \\
\text { on interpretation and } \\
\text { understanding in social } \\
\text { interactions }\end{array}$ & $\begin{array}{l}\text { Emancipatory with a } \\
\text { focus on criticism and } \\
\text { liberation }\end{array}$ \\
\hline Type of interaction & Man - nature & Man - man & Man - self \\
\hline Kind of knowledge & $\begin{array}{l}\text { Instrument (causal } \\
\text { explanation) }\end{array}$ & $\begin{array}{l}\text { Practical } \\
\text { (understanding) }\end{array}$ & Emancipation (reflection) \\
\hline $\begin{array}{l}\text { Underlining } \\
\text { paradigm }\end{array}$ & Functionalist/Positivist & Interpretative & Radical/Critical \\
\hline $\begin{array}{l}\text { Research methods } \\
\text { and inquiries }\end{array}$ & $\begin{array}{l}\text { Empirical-analytic } \\
\text { methods }\end{array}$ & Hermeneutic methods & $\begin{array}{l}\text { Critical theory, critical } \\
\text { science }\end{array}$ \\
\hline
\end{tabular}


Many management disciplines, including project studies, have developed by transcending the three kinds of knowledge, beginning with a strongly technical orientation, moving forward to more interpretative/practical interests, and then developing a stronger emancipatory human interest (Smyth and Morris, 2007).

Many scholars argue that the emancipatory interest leads to critical studies, which is understandable, as it follows Habermas' key argument and motivation. We argue that critical studies is one of several alternative research traditions following the emancipatory interest, particularly if understood as questioning stated for granted practices, and to explore approaches to transform the status quo. Habermas himself proposes other kinds of disciplines related to self-reflection as part of emancipatory interests, such as psychoanalysis (Habermas, 1972). In his later writings, Habermas distances himself from postmodernist thought and the Frankfurt School due to their tendency to be excessively negative and pessimistic.

Habermas is sceptical towards institutions, but he still believes that institutions, like humans, are malleable and can be changed for the better of society. Thus, an important role for scholars is to reflect and propose options. In his view, the communicative action would be an approach to culminate in such change (Finlayson, 2005). Indeed, in Burrell and Morgan's (1979) framework, Habermas' concept of emancipation is one of radical structuralism, with some elements taken from radical humanism. For example, critical utopian action research (Nielsen and Nielsen, 2006) is rooted in Habermas' thought and offers a critical yet pragmatic engagement with practice, with a view to reframing taken-for-granted assumptions of our society, creating utopians, and later, pragmatically considering in which form these utopians would be executed in practice.

Therefore, inspired by the emancipation interest and Habermas' later work, we propose an extension of the concept to include other forms of (self-) reflection that foster change. ${ }^{3}$ In this regard, emancipatory research, i.e. research adhering to emancipatory interests and ways of knowing, would not be limited to

\footnotetext{
${ }^{3}$ We understand that scholars of Habermas may disagree with our wide interpretation of the concept. For this reason, we are explicit about the proposed extension being 'inspired by' instead of 'equal to' Habermas' concept of emancipation.
} 
critical studies, but could include, for example, the introduction of new concepts, the presentation of cases to trigger new ideas and alternative understandings, and critical analysis of current practices showing that there is something unusual and perhaps even 'wrong' with the way they operate. Emancipatory studies could thus also point out potential 'ways out', not necessarily 'solutions' but, at least, optimistic outlooks and identification of practices that work differently, thereby opening space for what 'could be' as opposed to only what 'is'.

Such studies and scholars would be cognisant of the potential impact of their research and would not claim to be neutral, but would instead carefully consider and discuss the potential implications of what they propose. Emancipatory interests, therefore, presuppose the power to ask questions and the potential for dialogue, which are not always available. Habermas' critics argue that the issue of power is underplayed in his work and yet fundamental for the exercise of emancipatory interests. We agree, yet argue that for the purpose of discussing developments of research, we do not need to establish solutions for how emancipatory interests can be ultimately pursued, but rather acknowledge that they exist and in many different formats. Therefore, the criticism only stresses our point of being attentive of different opportunities for emancipatory interests to surface, which includes but is not limited to critical studies and critical theory.

\section{Three Types of Project Studies}

We apply Habermas' theory of knowledge-constitutive interests to project studies to propose three types: type 1 , type 2 and type 3 , respectively.

Type 1 has a technical interest with a main focus on prediction and control, and looks for causal explanations. Usually, but not exclusively, type 1 frames research in projects, for projects and for project studies. It mostly focuses on project processes. Research tends to be paradigmatic, and refines classic and conventional topics in projects, adding some contributions to the field. This research has been analysed by many authors and has been given various names, including projects-as-plans research (Packendorff, 1995) 
and the optimisation school (Söderlund, 2011). It also includes broader success-oriented research in an attempt to find the ultimate links between success criteria and success factors (Jugdev and Müller, 2005).

Type 2 is connected to the deep-seated interest on understanding the nature and dynamics of social systems more generally. It values applications and developments of theories and models as intellectual tools for analysing key aspects of the social world of projects. The consequence of this interest is that existing research adhering to the type 2 logic perceives projects as unique opportunities to study and to contribute to particular theoretical questions in organisation theory and general management. Projects are recognised as temporary organisations and contexts for theoretical development and empirical inquiry. An example of work in this area is what is oftentimes referred to as the Scandinavian School of Project Management (Lundin and Söderholm, 1995; Sahlin-Andersson and Söderholm, 2002). Its focus is on understanding the characteristics, nature and behaviours of projects as temporary organisations, and its wider implications on creativity, learning and innovation.

While interested in theories and theorising, type 2 research tends to start from a deep understanding of and interest in the practice and actuality of projects. In this regard, type 2 research follows Nicoline's (2009) idea of zooming in and zooming out, i.e. the continuous and iterative move from zooming in to practices and zooming out to the theory.

The work in this area has contributed to shifting project studies from being rather self-centric and not very well respected for developing relevant and theoretically rich research, to receiving more recognition and attention from fellow scholars in allied management disciplines (Kwak and Anbari, 2009). The IRNOP network, which was launched in 1993 and organised its first conference in 1994, has certainly played an important role. The track at EURAM (and later in EGOS) on project organising has also been important to drive this development forward (Söderlund and Maylor, 2012).

Type 2 is rather disconnected and is often in strong opposition to type 1. Most typically, papers subscribing to this type of project study begin with a departure and profound critique of type 1, arguing 
that type 1 research is too rationalistic, with limited grounding on current practices and lacking social science framing.

Type 3 is based on the human interest of emancipation, where critical reflection culminates in deliberate changes in the status quo. In project studies, such research usually builds on type 2 research and partly on type 1 as well. It reconciles the search for transforming the status quo with a deep understanding of practices and solid theories in search of reflection and change. Consequently, scholars conducting type 3 research are usually engaged in project practice and their contexts, and understand the 'realities' of the profession. However, they also challenge its inherent assumptions, and positions opportunities to rethink and transform them. Hence, the focus is not only on deconstructing and problematising, but also in contributing to the development of pragmatic (and contextualised) ways forward.

Similar to type 2, scholars subscribing to type 3 research usually engage in conversations within general management as well as our community. They also recognise the potential for contributions to general theory within but also outside management, most notably psychology, sociology and political science. In this regard, they not only contribute with innovative ideas to the project studies but also to management and organisation theory.

While type 2 research starts with a departure from type 1 research, type 3 research is inspired by Alvesson and Sandberg's (2011) suggestions to question assumptions of a scholarly field. In this regard, type 3 research not only questions assumptions of their own 'way of thinking' within project studies, but also ontological, epistemological and methodological assumptions shared across project studies as an academic community and research domain.

For type 3 scholars, research and education are not neutral. Ethical dilemmas and implications of the choice of topic and empirical contexts are key concerns, and in some cases, even the motivation of the research. In this regard, research questions here can challenge political, moral and gender-related assumptions within the field. They reflect on the examples and case studies they would like to use, 
searching, for instance, for more ethical projects that engage with the public, or alternatively, hold a critical view on the potentially negative effects of projects in local and global communities. Hence, type 3 research has a more active role in the development of our society and the impact of projects in society. Not surprisingly, we observed type 3 scholars also engaging with media, impacting companies and their management, as well as policy by engaging with the general public and governmental institutions.

Finally, scholars working in accordance with the ideas of type 3 research usually acknowledge the importance of project studies as a community, and the need to harvest this community, as opposed to (only) joining other communities. With that said, these scholars maintain strong linkages with external communities, publish in highly rated journals of general management and organisational theory, bring inspiration from these fields, while also caring and contributing to the development of the project research community, and acting as ambassadors of our community, whether explicitly or through their own outstanding research.

Unlike type 1 and type 2, type 3 is still in its infancy, rather rare (in projects and also general management) and seems very hard to develop. Project scholars can very quickly become too involved in the struggles of the day-to-day life of project managers and end up acting as consultants, with limited theoretical contributions. There is also the potential limitation of becoming too theoretical, divorced from the richness of the project context and the required pragmatism to change the status quo and 'fight for' emancipation.

Table 2 presents an overview of these three types of scholarly inquiry and modes of project research, which are more appropriate for the development of different knowledge-constitutive interests. Our aspiration is to draft a typology, i.e. 'a conceptually derived interrelated set of ideal types that explain a dependent variable' (Niknazar and Bourgault, 2017, p. 194). Using this rather positivist language, our 'dependent variable' is Habermas' knowledge interests, i.e. technical, understanding and emancipation; thus, the different types will be more likely to attain their respective interests. 
Unlike a classification, they are three 'ideal' types in that they are simplifications of actual research practices. Some scholars and studies can cut across two types or attend to only a few of the aspects characterised below. Most studies, however, would tend to be principally positioned in either one of these three types of research.

Although we advocate for more type 3 in project studies, we do not suggest that type 3 is superior to the other types. Instead, we welcome the heterogeneity of the field, arguing that all three knowledge interests are relevant and call for more cross-fertilisation.

Table 2: Application of the Theory of Knowledge-Constitutive Interests to Project Studies (adapted from Geraldi and Söderlund, 2016)

\begin{tabular}{|l|l|l|l|}
\hline Characteristics & Type 1 & Type 2 & Type 3 \\
\hline $\begin{array}{l}\text { Knowledge- } \\
\text { constitutive } \\
\text { interest }\end{array}$ & Technical interest & $\begin{array}{l}\text { Understanding } \\
\text { interest }\end{array}$ & Emancipatory interest \\
\hline $\begin{array}{l}\text { Understanding } \\
\text { of projects }\end{array}$ & $\begin{array}{l}\text { Projects as objects that } \\
\text { can be controlled } \\
\text { through feedback- } \\
\text { monitored instrumental } \\
\text { action. }\end{array}$ & $\begin{array}{l}\text { Projects as intriguing } \\
\text { phenomena or } \\
\text { contexts to be } \\
\text { understood. }\end{array}$ & $\begin{array}{l}\text { Projects as contemporary phenomena, } \\
\text { temporary with legacies that transform } \\
\text { organisations and society, but are also the } \\
\text { contexts for social interactions, prone } \\
\text { toward controversies but also } \\
\text { reconciliations }\end{array}$ \\
\hline $\begin{array}{l}\text { Empirical } \\
\text { settings }\end{array}$ & $\begin{array}{l}\text { Any projects (projects } \\
\text { are seen as similar and } \\
\text { comparable, and the } \\
\text { aim is to develop } \\
\text { general theories of } \\
\text { project management) }\end{array}$ & $\begin{array}{l}\text { Projects as lived } \\
\text { experience } \\
\text { (projects are } \\
\text { particular and a } \\
\text { subjective } \\
\text { experience) }\end{array}$ & $\begin{array}{l}\text { Conscious choice of projects - search for } \\
\text { 'talking dogs' with prominent ethical, } \\
\text { theoretical and/or practical } \\
\text { value/uniqueness }\end{array}$ \\
\hline $\begin{array}{l}\text { Impact on } \\
\text { practice }\end{array}$ & $\begin{array}{l}\text { Mostly prescriptive and } \\
\text { normative, attempting } \\
\text { to 'solve' the problem }\end{array}$ & $\begin{array}{l}\text { Actuality of project. } \\
\text { Mostly descriptive, } \\
\text { with some } \\
\text { implications to } \\
\text { practice and some } \\
\text { theorising }\end{array}$ & $\begin{array}{l}\text { Legacy in contributing to theory and/or } \\
\text { practice (impactful theoretical } \\
\text { development, preferably rigor and } \\
\text { relevance), which often invites reflection } \\
\text { and transformation of taken-for-granted } \\
\text { assumptions of the status quo. }\end{array}$ \\
\hline
\end{tabular}

\section{Levels of analysis in project studies}

From largely being a field devoted to the management of single projects (Söderlund, 2004a), research now spans a number of levels of analysis ranging from the individual to society. At the individual level, we observe the increasing recognition of the importance of individuals to projects (Palm and Lindahl, 2015), but also of projects to individuals, their careers, self-management, self-esteem, motivation and 
competence development (e.g., Ekrot et al., 2016; Muller and Turner, 2006). It draws largely on psychology, behavioural and learning theories. Studies inquire into the life and conditions of project-based work in general, and more specifically, into topics such as the motivation and competencies of project workers.

We also note the increasing impact of projects on geographical clusters (Grabher and Thiel, 2014), individual firms (Brady et al., 2004; Söderlund and Tell, 2009) and society at large (Lundin et al., 2015). There has also been a strong movement upwards to cover the organisational, strategic and corporate challenges facing organisations largely occupied in project business. This has included, but has not been limited to, topics such as project portfolio management, program management, learning across projects, the evolution of organisational-level project competence and the role of project capabilities in organisations. Projects become the conduit to several kinds of value-generating activities within the firm, including the realisation of strategy and the transformational changes it requires (Morgan et al., 2008). Not only is the context created for and around projects a key success factor, but it also largely determines how projects are done, and their impact and legacy (see for instance Dille and Söderlund, 2011; Morris and Geraldi, 2011).

Moving even further upwards are the analyses of the macro-level points of the project-oriented society (Gareos and Huemann, 2001; Jensen, 2012; Lundin et al., 2015) and the new spirit of project-oriented capitalism (Boltanski and Chiapello, 2006). This is also an important topic in a recent book authored by leading project scholars on the nature and consequences of project society (Lundin et al., 2015). What these contributions show is that the macro level in project studies is not necessarily only about the firm level, but a way of addressing a significant feature of Western society and defining our contemporary human condition (Fough Jensen et al., 2016). Thus, projects became a key unit of economic and social action, shaping sectors (Grabher, 2002; e.g. Sydow, 2004), society (Lundin et al., 2015) and who we are (Fough Jensen et al., 2016). Hence, the focus on the project as the primary level of analysis is relevant but 
no longer sufficient to understand the growing complexity of projects, and their impact on individuals, organisations and society.

In several other domains of management and organisation studies, different levels of analysis receive growing attention. For example, organisation theory and organisation behaviour have a tradition of organising knowledge across levels of analysis, in particular the individual, team/group, organisation and their relationship with the context (see, e.g., Hatch and Cunliffe, (2013) and most contemporary textbooks on organisation theory and organisation behaviour). In the field of human resource management (HRM), the editors of the Oxford Handbook of Human Resource Management summarised the current state of this field by making a distinction between macro HRM and micro HRM (Boxall et al., 2007). It should be pointed out that levels of analysis extract much more than merely a form of organising knowledge. The idea around multi-level theorising and the micro-foundations of strategy and organisation are telling examples of this development (e.g., Geels, 2011).

However, current classifications of project studies do not cover the current diversity within the field. For example, Söderlund's (2011) conceptualisation of schools focuses specifically on the project level (optimisation, factor, contingency, behaviour, relationship, governance and decision). Turner et al. (2010) emphasise the need to make a broader account of the field that transcends the project level and embraces the individual as a level of the analysis in what they termed 'social systems'.

In summary, we propose a spectrum of levels of analysis, moving from micro to meso to macro. We recognise that there are different levels of analysis also within a level, e.g. the micro level contains both individuals and teams, and the macro level refers to supra-organisational but also societal levels. Indeed, the levels of analysis are a spectrum, not the anchoring points. With that said, establishing some anchoring points facilitates the discussion of 'ideal types' of research. In line with other knowledge areas, we anchor this spectrum in the following three levels: 
Macro project studies: project portfolio, project society, firm level, program management, strategy, corporate change, project ecologies, industry development, innovation at the firm level, project capabilities, project competence at the firm level, inter-project learning, learning landscapes.

Meso project studies: project level explorations, collaboration, cooperation, coordination problems in projects, time management, communication management - the classic project management body of knowledge (PMBoK) and textbook topics, culture in projects, conflicts in projects, temporary organisation, deadlines in projects, planning in projects, learning in projects, knowledge integration at the project level, competence at the project level and so on. Many probably would argue that this would be the most important level of inquiry for project studies (and, historically, the level that most research has focused on). Inquiries at the project level to a great extent build the very foundation of the field and provide the organisational entity and collective act that constitute much of the basis for current theorising. First, if there are no projects, there will be little need for project studies. Second, the understanding of projects - what they are, why they exist and how they behave - forms the theoretical foundations for inquiries at the micro and macro levels of analysis (Söderlund, 2004b). Accordingly, we suggest that the project level constitutes the meso level of analysis, which for obvious reasons plays a particularly important role for project studies.

Micro project studies: individual-level studies in projects, people in projects, groups and teams in projects, psychology in projects, project competence at the individual level, project skills, project careers, project management careers, motivation, project overload, project teams, project teaming and virtual teams. Much research has emphasised the increasing importance of individual-level concerns in project studies. Scholars have investigated how people cope with stressful project work situations (ZikaViktorsson et al., 2006), how project participants develop a career over time and how they learn from projects. These studies also pay attention to team-level interactions - how micro-organisation units operate and function in the project context - highlighting the unique nature of the project contexts, for 
instance, with regard to swiftly building trust among participants (Meyerson et al., 1996) and responding to deadline pressure (Gersick, 1988).

These distinctions are by no means new, but to our knowledge, they have not been laid out explicitly as a guide to cover current research in project studies. Other scholars have made reference to a similar kind of idea, although not with an explicit focus on the study of projects. For example, Hedlund (1994) noted the importance of making distinctions between the individual, group and firm level in understanding knowledge management. Prencipe and Tell (2001), in a paper addressing various strategies for interproject learning, relied on a distinction between the organisation, team and individual levels to examine the location of learning in project-oriented firms. The levels are also used implicitly in conferences to divide themes of research in projects (for instance, IRNOP conferences have had people/HR, strategy and portfolio management as themes). Therefore, it is useful to make this distinction more explicit, and facilitate the production of knowledge and our own inquiries.

With that said, the distinctions between these three levels of analysis can be considered somewhat arbitrary. As mentioned above, micro, meso and macro levels function not as three discrete options but as a spectrum moving from extreme micro levels looking at individuals to macro levels exploring projects in society. The spectrum, therefore, contains individuals, teams, projects, programs, portfolios, firms and ecologies right up to the project society. We discuss three anchoring points in the micro, meso and macro levels for simplicity, and we are certainly aware that they might overlap.

\section{Combining levels of analysis and types of research}

The combination of levels and types of project research creates nine different kinds of inquiry within the area of project studies. To make it easy to remember, we have three levels: level 1, level 2 and level 3, and three research types: type 1 , type 2 and type 3 . Table 3 displays the nine resulting areas, which point to nine different kinds of research in project studies. We provide characteristics of these research areas and examples of past research. 
Table 3: Levels and Types of Research in Project Studies: A Framework

\begin{tabular}{|c|c|c|c|}
\hline & Type 1 & Type 2 & Type 3 \\
\hline $\begin{array}{l}\text { Level 3: } \\
\text { Society/ } \\
\text { Organisation }\end{array}$ & $\begin{array}{l}\text { Predict and improve } \\
\text { multi-project firms/ } \\
\text { project-based } \\
\text { organisations }\end{array}$ & $\begin{array}{l}\text { - Understand the context } \\
\text { and its relationship with } \\
\text { projects, such as the } \\
\text { tensions and relationships } \\
\text { between temporary and } \\
\text { standing organisations } \\
\text { - Contribution to project } \\
\text { studies and organisational } \\
\text { studies, and partly to } \\
\text { strategy and innovation } \\
\text { - Example: Midler (1995) }\end{array}$ & 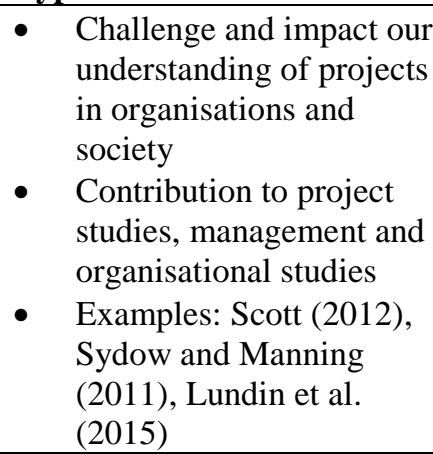 \\
\hline $\begin{array}{l}\text { Level 2: } \\
\text { Project }\end{array}$ & $\begin{array}{l}\text { - } \begin{array}{l}\text { Predict and improve } \\
\text { project management } \\
\text { processes }\end{array} \\
\text { - } \begin{array}{l}\text { Contribution to project } \\
\text { studies }\end{array} \\
\text { Example: Conventional } \\
\text { research on project } \\
\text { management, project } \\
\text { planning techniques, } \\
\text { breakdown structures. }\end{array}$ & $\begin{array}{l}\text { Understand temporary } \\
\text { modes of organising and } \\
\text { behaviour of projects } \\
\text { Contribution to general } \\
\text { management and } \\
\text { organisation studies, e.g. } \\
\text { process studies, } \\
\text { organising. } \\
\text { Example: Scandinavian } \\
\text { School of Project } \\
\text { Management, work on } \\
\text { temporary organising }\end{array}$ & $\begin{array}{l}\text { Challenge and impact our } \\
\text { understanding of projects } \\
\text { and temporary } \\
\text { organisations } \\
\text { Contribution to project } \\
\text { studies and beyond, e.g. } \\
\text { our understanding of } \\
\text { organisations and } \\
\text { organising practices more } \\
\text { generally } \\
\text { Examples: Bechky } \\
\text { (2006), Hodgson (2004) }\end{array}$ \\
\hline $\begin{array}{l}\text { Level 1: } \\
\text { Individual/ } \\
\text { Team }\end{array}$ & 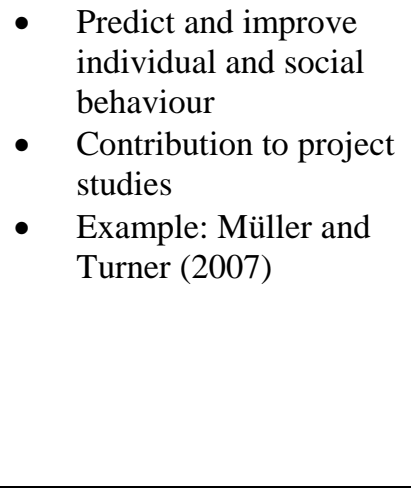 & $\begin{array}{l}\text { - Understand individual } \\
\text { and social behaviour } \\
\text { - Contribution to } \\
\text { leadership, human } \\
\text { resource, organisational } \\
\text { behaviour } \\
\text { - Examples: Partington et } \\
\text { al. (2005) }\end{array}$ & $\begin{array}{l}\text { Challenge and impact our } \\
\text { understanding of } \\
\text { individual and social } \\
\text { behaviour } \\
\text { Contribution to project } \\
\text { studies and beyond, e.g. } \\
\text { organisation studies, } \\
\text { organisational behaviour } \\
\text { and leadership } \\
\text { Examples: Hodgson et al. } \\
\text { (2011), Lindgren and } \\
\text { Packendorff (2006) }\end{array}$ \\
\hline
\end{tabular}

Each cell contains the different theoretical viewpoints originally presented in the schools of project

studies. However, the schools primarily addressed the project level (level 2). Therefore, the schools do not provide an accurate overview of the broader field of project studies as it has been presented here. The schools also did not explicitly discuss how research was conducted and the kind of knowledge it created.

As we make these more explicit, we can see that although scholars followed similar paradigms within each school, there have been studies with different paradigms within a school, for example, success factors from a type 3 perspective, deconstructing the impact of success criteria in projects (Cicmil and 
Hodgson, 2006). Crossing types of research within a level, or levels within a research type can, therefore, open space for new and interesting inquiries of research.

For aspiring scholars or scholars outside project studies, our suggested framework offers a tentative map of research and potential research opportunities. For established project scholars, the framework may be useful for generating a better understanding and a differentiation between past research and current literature. It might also constitute a platform for exploring new topics and modes of conducting empirical research. For example, one way of using the framework is to consider the kind of interests the scholars would like to pursue, and the competencies they have in terms of topics of research. This will position them in the framework. They can then compare that position with the current position of the extant literature on the topic, and explore potential future developments within the cell or by moving between cells.

The next paragraphs describe ideal types of scholars and research within each of the cells. Our descriptions are not to be followed strictly, but offer instead loose contours of the different cells. While types 1 and 2 have been widely acknowledged, type 3 is still emerging and hitherto less discussed. Therefore, our focus is on exploring type 3 research across the three different levels of analysis.

A typical type 1 study in the micro level seeks to identify traits and competencies of successful project managers (Muller and Turner, 2006) and teams for different types of projects and contextual variables (Malach-Pines et al., 2009). The research suggests the relevance of individuals and competencies for project success.

Moving into the meso level, type 1 research typically explores potential methods to manage projects and their impact on project performance. Contemporary research here accepts the need for contextualisation of the methodology and proposes alternative approaches to the classic front-end loaded and waterfall methodologies. Example include research on waterfall vs. agile methodologies and other variations, such as the spiral model (Boehm, 1988; Cohen et al., 2004). Contributions from design thinking helped break 
away from the classic process methodology, calling for stronger links with users, and highlighting the significance of co-creation and iterative problem-solving.

At the macro level, typical type 1 research looks for organisational solutions for multi-project organisations, e.g. Kwak and Ibbs (2002) and Cooke-Davies et al. (2003). Research on maturity levels is a good example. Its impact in practice is significant as practitioners find such models useful for benchmarking themselves with other firms and providing clear pathways to improve project capability.

Type 1 research is still relevant and important in terms of validating our current knowledge. However, this research is partly divorced from the real struggles in the 'reality' (realities) of projects, and/or 'big questions' and trends in general management and the world around us. The response to this criticism has been a call for research on the actuality of projects (Cicmil et al., 2006) and the need to explore what really goes on in projects (Söderlund, 2005).

At the micro level, type 2 research explores topics related to individuals and teams in projects. For example, research in leadership does not try to describe the characteristics of ideal leaders. Individuals and teams are the level of analysis, but they are understood within a broader ecosystem. For example, Partington et al. (2005) applies Sandberg's work to conceptualise the competence of program managers. Their study explores different levels of conception that program managers had about their work. Program managers act in accordance to how they perceive their context and their role in this context. As this differs from person to person, the roles people perform ultimately also differ. Therefore, the work challenges a widely accepted view on work-worker fit, as the work defines the worker and the worker defines the work. Their research suggests that program managers who possess a broader understanding of their role in relation to the context tend to act more competently. Here, a concept from management is applied to the project context, and contributes to the development of our understanding of competence in projects. However, its contributions to general management are limited. The work was also published in this journal and written for the project scholar community. 
The focus of research at the meso level is the project, often conceived as a temporary organisation. The research covers a wide a variety of studies, including project behaviour, project governance and peculiarities of temporary organising. For example, this has been the focus of Scandinavian scholars, who opened space for theorising as they positioned projects as temporary organisations. Classic work in the area include the 'Special Issue on Project Management and Temporary Organisations' published in 1995 in the Scandinavian Journal of Management (e.g., Lundin and Söderholm, 1995; Packendorff, 1995).

Work at the macro level addresses the context around projects and builds to a greater extent on established theories from general management, strategy and organisation studies, and contributes significantly to the project domain, but also extends original literature. An example is the seminal work of Midler (1995) on the projectification of the firm. Midler observed a shift in how work was organised in Renault and proposed increasing the number and relevance of projects within organisations, offering new forms of organising. The work paved the way for Cooper's work on project portfolio management, which provides practical insights on coordinating and selecting several projects in innovation and new product development literature. The work is also central for developments in multi-project firms, and later, the programmification of the firm, a term coined by Maylor et al. (2006) who point to an even further intensification of the use of projects in firms.

These are just examples. Type 2 research has had outreach within and beyond project studies. The research is relevant and provides the theoretical support of the field. However, the research tends to be mostly focused on contributing to the literature, and tends to abstain from political and ethical discourses. It also runs the risk of being divorced from the realities of project managers and shies away from providing normative and prescriptive guidance based on research findings.

In the next section, we propose examples of project scholars and works, which could be considered type 3 . These are only examples and not representative of the current research in the field. The idea is, instead, to explore the possibility of undertaking this type of research, despite its difficulties. Our second intention is 
to identity potential opportunities for future research and methodological approaches for furthering the type 3 research agenda.

\section{Exploring type 3 research}

There are several research opportunities within each of the identified 'cells', i.e. in the crossroads between the level of analysis and the type of research. In this article, we focus on the research opportunities in two areas: first, moving topics of study between cells; and second, opportunities for type 3 . We believe these two approaches to look for research opportunities have more potential for the development of new, robust, impactful and ethically sound research, and in so doing, shaping project studies in a bright and interesting light. In the following, we offer a few examples of research questions and past studies subscribing to type 3 across the different levels of analysis, as well as potential forms of cross-fertilisation across levels.

\section{Type 3 research at the micro level}

Exploring the impact of new forms of organising and implications of project society to the individual and team levels opens up promising and relevant topics for research at the micro level, such as new forms of self-organisation and distributed forms of leadership. This implies research exploring alternatives to leaders and leadership - engaging in analysis of leaderless projects in agile settings, collective leadership, and modern forms of co-workership, namely, followership. This would also, but to a somewhat less extreme extent, include research that studies new kinds of leadership constellations, such as dual and shared leadership, and which investigates new ways that leadership might be pursued, including coaching, educating and transforming behaviour in projects.

Examples of past research on project studies include the work of Buchanan et al. (2007) and Lindgren and Packendorff (2009) on project leadership, which offer alternative understandings of project leadership, not centred on one person, but distributed or shared across several people in different phases of the projects. The works challenge our usual understanding of leadership and uses the project as a context to explore these different forms of leadership. 
Future research could continue this line of inquiry. For example, how can we lead as we move to a project society where professionals become their own companies, carefully crafting profiles in LinkedIn and Twitter, and search for meaningful contributions, and 'exciting' profiles? What are the implications of such societal shifts to the concept of leadership and interactions between people at the micro level? How can we lead ourselves and start projects more like movements than classic projects? What are the implications of such emerging forms of interaction to classic relationships in organisations based on concepts of hierarchy and the chain of command? Why do people accept leadership (traditional or now), or in other hands, why do people 'follow' someone to do a project? Why are people followed? How does the project per se influence the potential of attracting followers (and becoming leaders)?

Obviously, research at the micro levels are more than studies of leaders and leadership. It certainly involves studies of individuals and employees in projects, how they develop affiliations with organisations, and how they develop competencies and skills needed to live and learn in a modern project economy - of moving between projects and organisations on a continuous basis. Such studies would not only document the difficulties and challenges that such people face, but also explore practices that they rely on to deal with these challenges and opportunities.

For example, studies of contractors working in projects in the software industry (Evans et al., 2004), Sennett's (2011) more critical analysis of project-based work, and Tempest and Starkey's (2004) analysis of freelance workers' ability to learn are all representative studies of these kinds of inquiries.

Self-management becomes primordial in such contexts and open to an array of future research. For example, we could explore the delicate 'passage' between projects from the individual perspective, such as how do people move from project to project? How do they prepare themselves for the move? What kinds of strategies and tactics are used to cope with the move? How do they deal with the consequences of recurrently moving among projects, and how does this influence their mental health and work-life balance? How do concepts of path dependence help explain current positions and lock-ups? In a more 
critical realm, it could be asked what kinds of interests do such developments activate? What are the implications of such a society in the long-term to the individual?

Further potential work at the micro level follows Habermas' call for self-reflection and explores potential avenues for self-reflective project practices, and their cognitive, social and educational facets. For example, how could the education and professionalisation of project managers prepare them for a more reflective understanding of project practices? What contradictions does such reflection create as it clashes with outdated and difficult to change institutions in projects, such as project success? How can a reflective project practitioner address such controversies?

This research also has the potential to cross levels of analysis, and contribute to policy development at the macro level, which can potentially mitigate or at least regulate some of the loose ends developed through a project society, such as intermittent work conditions, retirement plans and the like.

\section{Type 3 research at the meso level}

From the three levels, the meso level has historically received the most attention and comprises more contributions and contributors, and although much has been covered in the past, there is still much more to be done. The meso level is dedicated to the study of projects as forms of organising, building on the ideas of temporary organisations, and adding a more critical dimension to the project, governance mechanism, knowledge, power and relationships.

Topics of study include but are not limited to project governance (and the several nuances thereof) (Clegg et al., 2002; Pemsel and Müller, 2012; van Marrewijk and Smits, 2016), decision-making and estimations (Flyvbjerg et al., 2009) and inter-organisational relationships (including but not limited to public-private partnerships [PPPs]). For example, the Heathrow T5 became a widely used example of innovative forms of managing relationships between partners in the project and developing an open culture. In addition, as the failed launch of T5 painfully confirmed, the case also points to the relevance of including key stakeholders in such agreements (Brady et al., 2006). 
This type of research is ultimately interested in establishing some kind of theory about projects in an attempt to unveil the very foundation of organising according to projects, answering such simple yet fundamental questions as why projects exist, how they differ and how they behave. Examples of recent studies engaging in more elaborate forms of theoretical inquiry include Scott et al.'s (2012) study of the nature and dynamics of global projects relying on institutional theory.

Future research in this area could, for example, elaborate on the unique properties of projects as temporary organisations to develop theories that could contribute explicitly to more general management and organisation studies. This could, for instance, include work on interdisciplinary communication in projects, the formation of trust among project partners in complex projects, and the creation of an interlanguage to allow for problem-solving capabilities in innovative projects. The ultimate idea here would then be to embark on offering novel answers to the questions of why projects exist, how they differ and how they behave.

\section{Type 3 research at the macro level}

At the macro level, studies explore the omnipresence of projects in society, within but also detached from single organisations. Projects form geographical and knowledge clusters (project ecologies), and become for some scholars a fundamental unit of economic and social action (e.g., Castells, 1996; Grabher and Thiel, 2014; Lundin et al., 2015). Lundin et al. (2015) propose the notion of the project society to explore the institutional and societal implications of intensifying project work. Jensen (2012) goes further and points to several fundamental shifts in our form of living as human beings and brings projects to the context of philosophy.

In a different context and theoretical grounding, the work by Manning and Sydow (Manning, 2010; Manning and Sydow, 2011) draws on structuration theory and subscribes to a processual view to explore project networks as a particular form of organising and as a way to understand the social embeddedness of organisational action. Their work highlights, for instance, how relationships between project partners shape projects, and the inherent actions taking place within them as well as across projects can become 
path dependent. Their framework primarily targets an explanation of how project-intensive industries evolve and how relationships among project actors recur and change over time.

Grabher and Ibert (2011) present a framework that looks at two kinds of project ecologies. According to these authors, the project ecology constitutes 'a relational space which affords the personal, organisational, and institutional resources for performing projects.' They identity two primary types of project ecologies: the cumulative project ecology and the disruptive ecology. From this end, they are able to explain the specific challenges facing project organising in different settings, and particularly, the kind of learning challenges and learning processes that are involved in different project-intensive industries.

\section{Type 3 research crossing levels of analysis}

Research opportunities by moving between cells can be explored by positioning the extant literature and shifting the focus to different types of inquiries or levels of analysis, and in so doing, enhancing the debate on the topic. The studies on project-based work conditions are good examples, which bridge concerns from the micro level of analysis to occurrences at the macro level. Research in this area has been presented in, among others, Styhre's (2006) work on bureaucratisation, Hodgson and Cicmil's (2007) study of professionalisation and standards, and Clegg and Courpasson's (2004) writings on power and pressures felt by project managers. One criticism here relates to the implications of the professionalisation of project managers, which does not necessarily lead to more competent project managers nor improved project practices, and can, if misused, lead to bureaucratisation of project work. The work also contributes to the study of the professionalisation of knowledge workers, and the power within and outside project studies. It also points to required changes in the current power dynamics involved in projects and the institutional context developed for projects and, hence, have characters of interest of emancipation, criticism and pragmatism.

\section{Enhancing type 3 research}

Type 3 research is particularly challenging as it requires scholars to understand practices and to engage in practitioners' actualities and languages to produce findings that are relevant and pragmatic. Yet, the 
research must simultaneously have strong roots in theories and theoretical understanding within and beyond management and organisation studies. It might also require partnering with scholars with different competencies to embark on more advanced theoretically and methodologically informed research agendas.

Bringing in new disciplines is another approach to enhance type 3 research, by drawing on sociology, psychology and neurology for the micro and meso levels, and on political science, sociology and philosophy for the meso and macro levels. This would certainly require closer partnerships with scholars from other fields to be able to better position findings on projects and project practices in other theoretical domains. It might also open up new cross-disciplinary endeavours as projects, such as mega-projects, which might attract scholars from a diverse set of disciplines.

A final approach is to focus on pertinent problems in society - not on projects per se. For example, the United Nations' (UN) global goals for sustainable development offer a motivating set of wicked problems that require further understanding and research, many of which will be executed globally and locally through projects. The UN agenda addresses such challenges as poverty, well-being, education, gender equality, clean water, clean energy, sustainable cities, responsible consumption and production, and climate change. Addressing the big questions as a way to drive research is also well in line with what has been suggested at some of the leading conferences in project studies. For instance, the IRNOP 2015 conference in London had several sessions and plenary talks on the big questions in the field of project management, including climate change and the management of projects.

\section{Challenges ahead}

Project management has its roots in engineering and practice-oriented contributions on how to manage and organise projects and, hence, is deeply rooted in the technical human interest, largely relying on what we here referred to here as type 1 research. This is certainly still an important part of the life of the project scholar and certainly important to anyone interested in projects from a practical viewpoint. This is where 
we have most of our teaching, and where many business schools see the potential to attract a new market of managers - the project managers (Söderlund and Maylor, 2012).

Following technical human interest has been the hallmark of many project studies; however, this also comes with a series of challenges. The most important ones are probably the inability to see the wider picture and critically engage with taken-for-granted concepts, of not being able to contribute to theory on a more general level, and of not being recognised as a scholarly field of inquiry as such. Indeed, any academic trying to combine consulting with basic research knows about the problems we are talking about here, and would form the group of scholars attempting/conducting type 3 research.

While being too close to practices comes with its limitations, being too detached leads to a lack of understanding of practices and their complexity; hence, naïve theories emerge from the ivory tower with limited connection to the day-to-day 'realities' of project practitioners. Following Kant's well-known assertion, 'practice without theory is blind, theory without practice is empty', scholars (or at least a scholarly field of inquiry) need to walk the fine line between closeness to practice and engagement with extant theory. We presented some approaches to do this, and type 3 research has particular potential in this regard, but there are no silver bullets available.

\section{Conclusions}

The purpose of this article was to provide a comprehensive view of the growing field of project studies. We proposed the term 'project studies' as an umbrella concept encompassing the diverse research related to projects - the study of projects, alluding to the term 'organisation studies' as the study of organisations. Project studies includes but is not limited to project management, project organising, temporary organisation, multi-project management, management of projects and the nature of project-based work. We argue that while these different streams of research have different foci, methodological traditions, levels of analysis and interests, they are united in their interest in projects as a particular form of organising and participation at different degrees in the community of project scholars. 
We then developed a broad framework exploring the diverse field through the juxtaposition of levels of analysis and types of research. We observed that research transits the project as levels of analysis, and includes behaviours of individuals and teams at the micro level, as well as projects in portfolios within and outside organisational boundaries at the macro level. Accordingly, we proposed three levels of analysis: micro, meso and macro.

We also observed a variety of knowledge interests. Building on Habermas' theory of knowledgeconstitutive interests, we explored the styles as sources of different interests and, hence, inherently ethical decisions of the researcher. The traditional positivist tradition aims to 'solve the problems' of project organising and increase its efficiency and effectiveness through better understanding of causal relationships surrounding projects. Interpretative research is grounded on our inherent interest to understand the world around us, but not necessarily 'solve' it. Rather, this research explores perceptions, behaviours and sees the world not so much in terms of causal-links, but complex networks with interesting cases and possibilities for learning. This forms what we call type 1 and type 2 research, respectively. Type 3 connects types 1 and 2, and connects to problems not within project studies, but beyond. Likewise, attempts for theorising have an impact beyond the field of project studies. Moreover, type 3 research is critical at its core. It follows the interest of emancipation and the pragmatic desire for changes in the status quo, not in an optimisation lens as in typical normative and positivist research. Rather, it is the reorganisation of inherent contradictions, giving voice to minorities while addressing major economic and social problems.

The juxtaposition of levels of analysis and types of research offers a matrix with nine areas to position research contributions and to identify potential opportunities in the field of project studies. We argue the framework can be used to identify new opportunities for research as some 'cells' in the grid are less populated than others for different topics of study. Usually, extending current treatments of problems and topics to different levels of analysis and types of research form potentially insightful research in project 
studies. We would also welcome the strengthening of type 3 research across the three primary levels of analysis addressed in the present paper.

This paper provides a framework to encourage project scholars to reflect and become even more aware of nature and conduct of their research: the kinds of knowledge and interests they pursue, as well as the focus of their research. Our framework and analysis are exploratory and only build a tentative foundation for further exploration. We hope more will come that continue along these lines as well as criticise the main ideas presented here. 


\section{References}

Alvesson, M., Sandberg, J., 2011. Generating Research Questions Through Problematization. Acad. Manag. Rev. 36, 247-271. doi:10.5465/AMR.2011.59330882

Bechky, B.A., 2006. Gaffers, Gofers , and Grips : Role-Based Coordination in Temporary Organizations 17, 3-21. doi:10.1287/orsc. 1050.0149

Berger, P., Luckmann, T., 1966. The social construction of knowledge: A treatise in the sociology of knowledge. Open Road Media, Soho, NY.

Boehm, B.W., 1988. A spiral model of software development and enhancement. Computer (Long. Beach. Calif). 21, 61-72. doi:10.1109/2.59

Boltanski, L., Chiapello, E., 2006. The New Spirit of Capitalism. Int. J. Polit. Cult. Soc. 18, 161-188. doi:10.1007/s10767-006-9006-9

Borg, E., Söderlund, J., 2015. Liminality competence: An interpretative study of mobile project workers' conception of liminality at work. Manag. Learn. 46, 260-279. doi:10.1177/1350507613516247

Boxall, P.F., Purcell, J., Wright, P.M., 2007. The Oxford handbook of human resource management. Oxford University Press, Oxford.

Brady, T., Davies, A., Brady, T., Davies, A., Davies, A., 2004. Organization Studies to Exploitative Learning. doi:10.1177/0170840604048002

Brady, T., Davies, A., Gann, D., Rush, H., 2006. Learning to Manage Mega Projects: The case of BAA and Heathrow Terminal 5 1-12.

Bredillet, C.N., 2010. Blowing hot and cold on project management. Proj. Manag. J. 41, 4-20. doi:10.1002/pmj.20179

Buchanan, D.A., Addicott, R., Fitzgerald, L., Ferlie, E., Baeza, J.I., 2007. Nobody in charge: Distributed change agency in healthcare. Hum. Relations 60, 1065-1090. doi:10.1177/0018726707081158

Burrell, G., Morgan, G., 1979. Social paradigms and organizational analysis: Elements of the sociology of corporate life. Heinemann Educational, London.

Castells, M., 1996. The rise of the network society: The information age: Economy, society, and culture. Blackwell Publishing, West Sussex.

Chalmers, A., 1976. What Is This Thing Called Science? Open University Press, Berkshire.

Cicmil, S., 2006. Understanding Project Management Practice Through Interpretative and Critical Research Perspectives. Proj. Manag. J. 37, 27-38.

Cicmil, S., Hodgson, D., 2006. New possibilities for project management theory: A critical engagement. Proj. Manag. J. 37, 111-122.

Cicmil, S., Williams, T., Thomas, J., Hodgson, D., 2006. Rethinking Project Management: Researching the actuality of projects. Int. J. Proj. Manag. 24, 675-686. doi:10.1016/j.ijproman.2006.08.006

Clegg, S., Courpasson, D., 2004. Political hybrids: Tocquevillean views on project organizations. J. Manag. Stud. 41, 525-547. doi:10.1111/j.1467-6486.2004.00443.x

Clegg, S.R., Pitsis, T.S., Rura-Polley, T., Marosszeky, M., 2002. Governmentality Matters: Designing an Alliance Culture of Inter-Organizational Collaboration for Managing Projects. Organ. Stud. 23, 317-337. doi: $10.1177 / 0170840602233001$

Cohen, D., Lindvall, M., Costa, P., 2004. An Introduction to Agile Methods. Adv. Comput. 62, 1-66. doi:10.1016/S0065-2458(03)62001-2 
Cooke-davies, T.J., Arzymanow, A., 2003. The maturity of project management in different industries : An investigation into variations between project management models $21,471-478$. doi:10.1016/S02637863(02)00084-4

Crawford, L., Pollack, J., England, D., 2006. Uncovering the trends in project management: Journal emphases over the last 10 years. Int. J. Proj. Manag. 24, 175-184. doi:10.1016/j.ijproman.2005.10.005

Cunliffe, A.L., 2003. Reflexive Inquiry in Organizational Research: Questions and Possibilities. Hum. Relations 56, 983-1003. doi:10.1177/00187267030568004

Davies, A., Hobday, M., 2005. The business of projects: managing innovation in complex products and systems. Cambridge University Press, Cambridge.

Dille, T., Söderlund, J., 2011. Managing inter-institutional projects: The significance of isochronism, timing norms and temporal misfits. Int. J. Proj. Manag. 29, 480-490. doi:10.1016/j.ijproman.2011.02.007

Ekrot, B., Rank, J., Gemünden, H.G., 2016. Antecedents of project managers' voice behavior: The moderating effect of organization-based self-esteem and affective organizational commitment. Int. J. Proj. Manag. 34, 10281042. doi:10.1016/j.ijproman.2015.10.011

Evans, J.A., Kunda, G., Barley, S.R., 2004. Beach Time, Bridge Time, and Billable Hours: The Temporal Structure of Technical Contracting. Adm. Sci. Q. 49, 1-38. doi:10.2307/4131454

Finlayson, J.G., 2005. Habermas: A very short introduction. Oxford Press, Oxford.

Flyvbjerg, B., Garbuio, M., Lovallo, D., 2009. Delusion and Deception in Large Infrastructure Projects: Two Models for Explaining and Preventing Executive Disaster. Calif. Manage. Rev. 51, 170-193. doi:10.1225/CMR423

Fough Jensen, A., Thuesen, C., Geraldi, J., 2016. The projectification of everything: projects as a human condition. Proj. Manag. J. 47, 21-34.

Geels, F.W., 2011. The multi-level perspective on sustainability transitions: Responses to seven criticisms. Environ. Innov. Soc. Transitions 1, 24-40. doi:10.1016/j.eist.2011.02.002

Geraldi, J., Söderlund, J., 2016. Project studies and engaged scholarship. Int. J. Manag. Proj. Bus. 9, 767-797. doi:10.1108/IJMPB-02-2016-0016

Geraldi, J., Teerikangas, S., 2009. From project management to managing by projects: Learning from the management of M\&As, in: IRNOP - International Research Network on Organizing by Projects, 19-22 June. Montreal.

Gersick, C.J.G., 1988. Time and transition in work teams: towards a new model of group development. Acad. Manag. Jou 31, 9-41.

Grabher, G., 2002. Cool Projects, Boring Institutions: Temporary Collaboration in Social Context. Reg. Stud. 36, 205-214. doi:10.1080/00343400220122025

Grabher, G., Ibert, O., 2014. Distance as asset? Knowledge collaboration in hybrid virtual communities. J. Econ. Geogr. 14, 97-123. doi:10.1093/jeg/lbt014

Grabher, G., Ibert, O., 2011. Project Ecologies: A Contextual View on Temporary Organizations, in: Morris, P.W.G., Pinto, J.K., Söderlund, J. (Eds.), The Oxford Handbook of Project Management2. Oxford Univeristy Press, Oxford, pp. 175-198.

Grabher, G., Thiel, J., 2014. Coping with a Self-Induced Shock: The Heterarchic Organization of the London Olympic Games 2012. Soc. Sci. 3, 527-548. doi:10.3390/socsci3030527

Habermas, J., 1985. The theory of communicative action. Volume 2: Lifeworld and system: A critique of functionalist reason. Bacon Press, Boston.

Habermas, J., 1984. Theory of Communicative Action, Volume 1: Reason and the Rationalization of Society, 2nd ed. Beacon Press, Boston. 
Habermas, J., 1981. The Theory of Communicative Action, Volume 1: Reason and the Rationalization of Society. Polity.

Habermas, J., 1972. Knowledge and Human Interest. Polity Press, Cambridge.

Hatch, M.J., Cunliffe, A.L., 2013. Organization theory: modern, symbolic and postmodern perspectives. Oxford University Press, Oxford.

Hedlund, G., 1994. A model of knowledge management and the N-form corporation. Strateg. Manag. J. 15, 73-90. doi:10.1002/smj.4250151006

Hodgson, D., Cicmil, S., 2007. The politics of standards in modern management: Making "the project" a reality. J. Manag. Stud. 44, 431-450. doi:10.1111/j.1467-6486.2007.00680.x

Hodgson, D., Paton, S., Cicmil, S., 2011. Great expectations and hard times: The paradoxical experience of the engineer as project manager. Int. J. Proj. Manag. 29, 374-382. doi:10.1016/j.ijproman.2011.01.005

Hodgson, D.E., 2004. Organization project work : The legacy of bureaucratic control in post-bureaucratic organization. Organization 11, 81-100. doi:10.1177/1350508404039659

Husserl, E., 1970. The crisis of European sciences and transcendental phenomenology: An introduction to phenomenological philosophy. Northwestern University Press, Evanston.

Jacobsson, M., Lundin, R.A., Söderholm, A., 2015. Researching Projects and Theorizing Families of Temporary Organizations. Proj. Manag. J. 46, 9-18. doi:10.1002/pmj.21520

Jensen, A.F., 2012. The Project Society. Aarhus Universitetsforlag, Aarhus.

Jugdev, K., Müller, R., 2005. A retrospective look at our evolving understanding of project success. Proj. Manag. J. $36,19-31$.

Kloppenborg, T.J., Opfer, W.A., 2002. The Current State of Project Management Research: Trends, Interpretations, and Predictions. Proj. Manag. J. doi:10.1002/pmj

Knudsen, C., 2003. Pluralism, scientific progress, and the structure of organization theory, in: Tsoukas, H., Knudsen, C. (Eds.), The Oxford Handbook of Organization Theory. Oxford University Press, Oxford, pp. 262-288.

Kuhn, T.S., 1962. The Structure of Scientific Revolutions. Chicago.

Kwak, Y.H., Ibbs, C.W., 2002. Project Management Process Maturity (PM)2 Model. J. Manag. Eng. 18, 150-155. doi:10.1061/(ASCE)0742-597X(2002)18:3(150)

Kwak, Y.H., Anbari, F.T., 2009. Analyzing project management research: Perspectives from top management journals. Int. J. Proj. Manag. 27, 435-446. doi:10.1016/j.ijproman.2008.08.004

Lindgren, M., Packendorff, J., 2009. Project leadership revisited: towards distributed leadership perspectives in project research. Int. J. Proj. Organ. Manag. 1, 285. doi:10.1504/IJPOM.2009.027540

Lindgren, M., Packendorff, J., 2006. What's New in New Forms of Organizing ? On the Construction of Gender in Project-Based Work Monica Lindgren and Johann Packendorff. J. Manag. Stud.

Lundin, R.A., Söderholm, A., 1995. A theory of the temporary organization. Scand. J. Manag. 11, 437-455. doi:10.1016/0956-5221(95)00036-U

Lundin, R.A., Arvidsson, N., Brady, T., Ekstedt, E., Midler, C., Sydow, J., 2015. Managing and Working in Project Society. Cambridge University Press, Cambridge. doi:10.1017/CBO9781139939454

Malach-Pines, A., Dvir, D., Sadeh, A., 2009. Project manager-project (PM-P) fit and project success. Int. J. Oper. Prod. Manag. 29, 268-291. doi:10.1108/01443570910938998

Manning, S., 2010. The strategic formation of project networks: A relational practice perspective. Hum. Relations 63, 551-573. doi:10.1177/0018726709340954 
Manning, S., Sydow, J., 2011. Projects, paths, and practices: Sustaining and leveraging project-based relationships. Ind. Corp. Chang. 20, 1369-1402. doi:10.1093/icc/dtr009

Maylor, H., Brady, T., Cooke-Davies, T., Hodgson, D., 2006. From projectification to programmification. Int. J. Proj. Manag. 24, 663-674. doi:10.1016/j.ijproman.2006.09.014

Merton, R.K., 1973. The sociology of science: Theoretical and empirical investigations. University of Chicago Press, Chicago.

Meyerson, D., Weick, K.E., Kramer, R.M., 1996. Swift trust and temporary groups, in: Trust in Organizations: Frontiers of Theory and Research. Sage, Thousand Oaks.

Midler, C., 1995. "Projectification” of the firm: The renault case. Scand. J. Manag. 11, 363-375. doi:10.1016/09565221(95)00035-T

Morgan, M., Malek, W.A., Levitt, R.E., 2008. Executing your strategy. Harvard Business School Press, Boston.

Morris, P.W.G., 1994. The management of projects. Thomas Telford, London.

Morris, P.W.G., Geraldi, J., 2011. Managing the Institutional Context. Proj. Manag. J. 42, 20-32. doi:10.1002/pmj

Muller, R., Turner, J.R., 2006. Leadership Competencies and their Successful Application In Different Project Types. Irnop Vii 1-12.

Müller, R., Geraldi, J., Turner, R., 2007. Linking complexity and leadership competences of project managers.

Nicolini, D., 2009. Zooming in and zooming out: A package of method and theory to study work practices, in: Ybema, S., Yanow, D., Wels, H., Kamsteeg, F.H. (Eds.), Organizational Ethnography. SAGE Publications, London, pp. 120-138.

Nielsen, K.A., Nielsen, B.S., 2006. Methodologies in action research, in: Action and Interaction Research-beyond Practice and Theory. Shaker Publishing, Maastricht.

Niknazar, P., Bourgault, M., 2017. Theories for classification vs. classification as theory: Implications of classification and typology for the development of project management theories. Int. J. Proj. Manag. 35, 191203. doi:10.1016/j.ijproman.2016.11.002

Packendorff, J., 1995. Inquiring into the temporary organization: New directions for project management research. Scand. J. Manag. 11, 319-333. doi:10.1016/0956-5221(95)00018-Q

Padalkar, M., Gopinath, S., 2016. Six decades of project management research: Thematic trends and future opportunities. Int. J. Proj. Manag. 34, 1305-1321. doi:10.1016/j.ijproman.2016.06.006

Palm, K., Lindahl, M., 2015. A project as a workplace. Int. J. Proj. Manag. 33, 828-838. doi:10.1016/j.ijproman.2014.10.002

Partington, D., Pellegrinelli, S., Young, M., 2005. Attributes and levels of programme management competence: An interpretive study. Int. J. Proj. Manag. 23, 87-95. doi:10.1016/j.ijproman.2004.06.004

Pellegrinelli, S., 2011. What's in a name: Project or programme? Int. J. Proj. Manag. 29, 232-240. doi:10.1016/j.ijproman.2010.02.009

Pemsel, S., Müller, R., 2012. The governance of knowledge in project-based organizations. Int. J. Proj. Manag. 30, 865-876. doi:10.1016/j.ijproman.2012.02.002

Pollack, J., 2007. The changing paradigms of project management. Int. J. Proj. Manag. 25, $266-274$. doi:10.1016/j.ijproman.2006.08.002

Pollack, J., Adler, D., 2014. Emergent trends and passing fads in project management research: A scientometric analysis of changes in the field. Int. J. Proj. Manag. 33, 236-248. doi:10.1016/j.ijproman.2014.04.011

Prencipe, A., Tell, F., 2001. Inter-project learning : processes and outcomes of knowledge codification in project- 
based firms 30, 1373-1394.

Resolution, P., 2009. CHAOS Summary 2009 1-4.

Sahlin-Andersson, K., Söderholm, A., 2002. Beyond project management: New perspectives on the temporarypermanent dilemma. Liber, Malmö.

Sandberg, J., 2000. Understanding human competence at work: An interpretative approach. Acad. Manag. J. 43, 925. doi:10.2307/1556383

Schütz, A., 1945. On Multiple Realities. Philos. Phenomenol. Res. 5, 533-576.

Scott, W.R., 2012. The institutional environment of global project organizations. Eng. Proj. Organ. J. 2, $27-35$. doi:10.1080/21573727.2011.634546

Sennett, R., 2011. The corrosion of character: The personal consequences of work in the new capitalism. WW Norton \& Company, New York.

Shapira, Z., 2011. “I’ve Got a Theory Paper-Do You?”: Conceptual, Empirical, and Theoretical Contributions to Knowledge in the Organizational Sciences. Organ. Sci. 22, 1312-1321. doi:10.1287/orsc.1100.0636

Smyth, H.J., Morris, P.W.G., 2007. An epistemological evaluation of research into projects and their management: Methodological issues. Int. J. Proj. Manag. 25, 423-436. doi:10.1016/j.ijproman.2007.01.006

Styhre, A., 2006. The bureaucratization of the project manager function: The case of the construction industry. Int. J. Proj. Manag. 24, 271-276. doi:10.1016/j.ijproman.2006.01.002

Sydow, J., 2004. Project-Based Organizations, Embeddedness and Repositories of Knowledge: Editorial. Organ. Stud. 25, 1475-1489. doi:10.1177/0170840604048162

Söderlund, J., 2011. Pluralism in Project Management: Navigating the Crossroads of Specialization and Fragmentation. Int. J. Manag. Rev. 13, 153-176. doi:10.1111/j.1468-2370.2010.00290.x

Söderlund, J., 2005. What project management really is about: alternative perspectives on the role and practice of project management. Int. J. Technol. Manag. 32, 371-387. doi:10.1504/IJTM.2005.007340

Söderlund, J., 2004a. Building theories of project management: Past research, questions for the future. Int. J. Proj. Manag. 22, 183-191. doi:10.1016/S0263-7863(03)00070-X

Söderlund, J., 2004b. On the broadening scope of the research on projects: A review and a model for analysis. Int. J. Proj. Manag. 22, 655-667. doi:10.1016/j.ijproman.2004.05.011

Söderlund, J., Maylor, H., 2012. Project management scholarship: Relevance, impact and five integrative challenges for business and management schools. Int. J. Proj. Manag. 30, 686-696. doi:10.1016/j.ijproman.2012.03.007

Söderlund, J., Tell, F., 2009. The P-form organization and the dynamics of project competence: Project epochs in Asea/ABB, 1950-2000. Int. J. Proj. Manag. 27, 101-112. doi:10.1016/j.ijproman.2008.10.010

Tempest, S., Starkey, K., 2004. The Effects of Liminality on Individual and Organizational Learning. Organ. Stud. 25, 507-527. doi:10.1177/0170840604040674

Tinning, R., 1992. Reading Action Research: Notes on Knowledge and Human Interests. Quest 44, 1-14. doi:10.1080/00336297.1992.10484038

Turner, R.J., Huemann, M., Anbari, F.T., Bredillet, C.N., 2010. Perspectives on Projects. Routledge, Oxon.

van der Hoorn, B., Whitty, S.J., 2015. A Heideggerian paradigm for project management: Breaking free of the disciplinary matrix and its Cartesian ontology. Int. J. Proj. Manag. 33, 721-734. doi:10.1016/j.ijproman.2014.09.007

van Marrewijk, A., Smits, K., 2016. Cultural practices of governance in the Panama Canal Expansion Megaproject. Int. J. Proj. Manag. 34, 533-544. doi:10.1016/j.ijproman.2015.07.004 
Williams, T., 2005. Assessing and moving on from the dominant project management discourse in the light of project overruns. IEEE Trans. Eng. Manag. 52, 497-508. doi:10.1109/TEM.2005.856572

Winch, G.M., 2013. Escalation in major projects: Lessons from the Channel Fixed Link. Int. J. Proj. Manag. 31, 724-734. doi:http://dx.doi.org/10.1016/j.ijproman.2013.01.012

Zika-Viktorsson, A., Sundström, P., Engwall, M., 2006. Project overload: An exploratory study of work and management in multi-project settings. Int. J. Proj. Manag. 24, 385-394. doi:10.1016/j.ijproman.2006.02.010 